\title{
Phosphate-irrepressible Alkaline Phosphatase of Zymomonas mobilis
}

\author{
By G. P. F. MICHEL AND J. C. BARATTI* \\ Laboratoire de Chimie Bactérienne, CNRS, 31 chemin J. Aiguier, 13009 Marseille, France
}

(Received 2 August 1988; revised 7 November 1988; accepted 14 November 1988)

\begin{abstract}
The phosphate regulation and subcellular location of the hydrolytic enzyme alkaline phosphatase were investigated in the Gram-negative bacterium Zymomonas mobilis. The biosynthesis of alkaline phosphatase was not derepressed at a low phosphate concentration as is generally observed in other micro-organisms, nor was it repressed by high phosphate concentrations in the medium. The enzyme level was rather constant during the growth phases in batch culture, at a value at least 8.4-fold lower than that observed in Escherichia coli. The alkaline phosphatase of $Z$. mobilis was found associated with the membrane fraction after cell disruption, osmotic shock treatment or spheroplast formation. This is a rather unusual location, since most of the alkaline phosphatases from Gram-negative bacteria have been shown to be periplasmic enzymes. Activity staining on polyacrylamide gels after two-dimensional electrophoresis revealed two isoforms of alkaline phosphatase, each of approximate molecular mass $56 \mathrm{kDa}$. These two forms belong to a group including the more basic envelope proteins of $Z$. mobilis. Our results indicate that the enzyme from $Z$. mobilis differs markedly from typical alkaline phosphatases of other Gram-negative bacteria.
\end{abstract}

\section{INTRODUCTION}

The Gram-negative bacterium Zymomonas mobilis is an efficient ethanol producer and can tolerate the high levels of alcohol produced in the growth medium during fermentation (Swings \& De Ley, 1977; Montenecourt, 1985; Baratti \& Bu'lock, 1986). This micro-organism possesses biochemical mechanisms well adapted to an alcoholic environment and it is an interesting model for studying ethanol tolerance in bacteria. Ethanol has been shown to affect numerous biochemical processes, including protein export (Enequist $e$ t al., 1981), by acting on membrane organization (Ingram \& Buttke, 1984). Therefore it can be expected that the components of the export mechanisms of $Z$. mobilis are resistant to ethanol.

In order to understand such a mechanism and obtain information about the export machinery, it is necessary to know the location of the protein exported, as well as that of possible intermediates of the export process. Unfortunately, little is known about the structural arrangement and the biochemical composition of the $Z$. mobilis cell envelope. It has only been reported that although it presents a typical Gram-negative envelope structure (Doelle et al., 1982), Z. mobilis is mainly characterized by high levels of cis-vaccenic acid and phosphatidylcholine, a lipopolysaccharide (LPS) not containing KDO (3-deoxy-D-manno-octulosonate), heptose or $\beta$-hydroxymyristic acid (Tornabene et al., 1982) and a high hopanoid content (Bringer et al., 1985). These observations, which reflect an unusual envelope organization, suggest that this organism possesses biochemical mechanisms well adapted to growth in the presence of alcohol. The envelope proteins of $Z$. mobilis have not been extensively studied. Thus, any investigation of the properties of a cell-associated protein of $Z$. mobilis will contribute to a better knowledge of the physiology of this bacterium.

Alkaline phosphatase (EC 3.1.3.1) was selected as the exported protein for study. This periplasmic enzyme of Escherichia coli was used as a model system in some of the earliest attempts to understand the export process (Beckwith, 1987); and in other Gram-negative 
bacteria, proteins exhibiting alkaline phosphatase activity were shown to be envelopeassociated, reasonably stable and their activity easily assayed by following the colour change of the substrate $p$-nitrophenyl phosphate (Garen \& Levinthal, 1960). The present report deals with some of the properties of the alkaline phosphatase of $Z$. mobilis, namely those concerning the regulation of its biosynthesis and cellular location.

\section{METHODS}

Organisms and culture conditions. Z. mobilis ZM4 (ATCC 31821) was grown at $30^{\circ} \mathrm{C}$ without agitation either in a rich medium (containing, per litre: 20 or $40 \mathrm{~g}$ glucose, $5 \mathrm{~g}$ Bacto peptone, $3 \mathrm{~g}$ yeast extract, $3 \mathrm{~g}$ malt extract, $\mathrm{pH} 5$ ) or in a low-phosphate medium (per litre: 20 or $40 \mathrm{~g}$ glucose, $5 \mathrm{~g}$ sodium acetate, $5 \mathrm{~g}$ proteose peptone, $1 \mathrm{~g}$ $\left.\left(\mathrm{NH}_{4}\right)_{2} \mathrm{SO}_{4}, 0.5 \mathrm{~g} \mathrm{MgSO}_{4} .7 \mathrm{H}_{2} \mathrm{O}, \mathrm{pH} 5 \cdot 5\right)$. E. coli $\mathrm{K} 12$ was grown aerobically at $37^{\circ} \mathrm{C}$ in a low-phosphate medium of the following composition (per litre): $2 \mathrm{~g}$ glucose, $23.8 \mathrm{~g}$ HEPES, $5 \mathrm{~g}$ proteose peptone, $1.1 \mathrm{~g} \mathrm{NH}_{4} \mathrm{Cl}, 1.5 \mathrm{~g} \mathrm{KCl}$, $0.3 \mathrm{~g} \mathrm{MgCl}_{2}(\mathrm{pH} 7 \cdot 2)$.

Toluene treatment of cells. Toluene ( $50 \mu \mathrm{l}$ per $\mathrm{ml}$ of cell suspension) was added either directly to the culture medium, or after centrifugation $\left(7000 \mathrm{~g}, 5 \mathrm{~min}, 4^{\circ} \mathrm{C}\right)$ and resuspension in $10 \mathrm{mM}$-Tris/ $\mathrm{HCl}$ buffer $\mathrm{pH} 7 \cdot 4$. The toluene treatment was carried out at room temperature for $30 \mathrm{~min}$ with frequent and vigorous mixing.

Preparation of cell extracts of $Z$. mobilis. Cells grown in the low phosphate medium were harvested in the late exponential phase $\left(7000 \mathrm{~g}, 10 \mathrm{~min}, 4^{\circ} \mathrm{C}\right)$, resuspended in $0.1 \mathrm{vol} .10 \mathrm{mM}$-Tris $/ \mathrm{HCl} \mathrm{pH} 7.4$ and either disrupted after passage through a French pressure cell (two passages at $294 \mathrm{MPa}$ and one passage at $392 \mathrm{MPa}$ ), or ultrasonically disintegrated using a Branson Sonifier (12 periods of $15 \mathrm{~s}$ at $40 \mathrm{~W}$, with $45 \mathrm{~s}$ intervals between periods). Cellular debris and unbroken cells were removed by centrifugation $\left(4000 \mathrm{~g}, 10 \mathrm{~min}, 4^{\circ} \mathrm{C}\right)$. The supernatant (crude extract) was used immediately or stored at $-20^{\circ} \mathrm{C}$ in $20 \%$ (w/v) glycerol (final concentration) for detection of the alkaline phosphatase activity after polyacrylamide gel electrophoresis. Membranes were recovered in the pellet after ultracentrifugation of the crude extract $\left(170000 \mathrm{~g}, 90 \mathrm{~min}, 4^{\circ} \mathrm{C}\right)$.

Spheroplast formation. The method of Welsch (1958) was applied, with the following modifications. Cells were grown in the low-phosphate medium containing $4 \%(w / v)$ glucose. In the mid-exponential phase, the culture was diluted $1: 1(\mathrm{v} / \mathrm{v})$ with the same medium supplemented with $6 \%(\mathrm{w} / \mathrm{v})$ glycine and $40 \%(\mathrm{w} / \mathrm{v})$ sorbitol. Cells were further incubated at $30^{\circ} \mathrm{C}$; conversion to spheroplasts was complete after $16 \mathrm{~h}$ as shown by microscope observation. Spheroplasts were then centrifuged $\left(10000 \mathrm{~g}, 10 \mathrm{~min}, 4^{\circ} \mathrm{C}\right)$ and alkaline phosphatase, alcohol dehydrogenase and NADH oxidase activities were assayed in the pellet and in the supernatant.

Osmotic shock. Cells were osmotically shocked according to the method of Willis et al. (1974).

Sodium lauroyl sarcosinate (Sarkosyl) treatment. Membranes obtained after ultracentrifugation $(100000 \mathrm{~g}, 90$ min, $4^{\circ} \mathrm{C}$ ) of the crude extract were resuspended in $10 \mathrm{~mm}$ Tris/ $\mathrm{HCl} \mathrm{pH} 7.4$ and treated with $0.5-1 \%(\mathrm{w} / \mathrm{v})$ Sarkosyl for $30 \mathrm{~min}$ at room temperature. Detergent-insoluble membrane fractions were then sedimented $(100000 \mathrm{~g}, 90$ $\left.\min , 4^{\circ} \mathrm{C}\right)$.

Protein assay. Proteins were estimated as described by Schaecterle \& Pollach (1975) with BSA as a standard.

Phosphate determination. Phosphate concentration in the growth medium was determined according to Ames \& Dubin (1975).

Enzyme assays. Alkaline phosphatase was assayed in a reaction mixture containing $0.1 \mathrm{ml}$ enzyme extract and $0.9 \mathrm{ml}$ p-nitrophenylphosphate $\left(1 \mathrm{mg} \mathrm{ml}^{-1}\right.$ in $0.1 \mathrm{M}$-Tris/HCl, $\left.\mathrm{pH} 8\right)$. The amount of substrate hydrolysed per unit time was calculated from the absorbance of nitrophenol liberated, using a molar absorption coefficient of $1.62 \times 10^{4} \mathrm{M}^{-1} \mathrm{~cm}^{-1}$ at $410 \mathrm{~nm}$ (Torriani, 1966). One unit was defined as the amount of enzyme which liberates 1 $\mu \mathrm{mol}$ nitrophenol $\mathrm{min}^{-1}$.

Alcohol dehydrogenase activity was estimated by NADH formation according to the Merck procedure. The reaction mixture contained $0.8 \mathrm{ml}$ of a buffer prepared with $0.75 \mathrm{M}$-sodium pyrophosphate and $0.02 \mathrm{M}$-glycine $(\mathrm{pH}$ 8.8), $0.04 \mathrm{ml}$ ethanol, $0.067 \mathrm{ml} \mathrm{0.045} \mathrm{M}-\mathrm{NAD}^{+}$and $0.1 \mathrm{ml}$ enzyme extract. The enzyme activity per unit time was calculated from NADH formation monitored by absorbance at $340 \mathrm{~nm}$. The molar absorption coefficient of NADH in these conditions was $6.22 \times 10^{6} \mathrm{M}^{-1} \mathrm{~cm}^{-1}$. One unit was defined as the amount of enzyme producing $1 \mu \mathrm{mol}$ NADH $\mathrm{min}^{-1}$.

NADH oxidase activity was assayed as described by Osborn et al. (1972), and one unit was defined as the amount of enzyme oxidizing $1 \mu \mathrm{mol}$ NADH min $^{-1}$.

Polyacrylamide gel electrophoresis (PAGE). One-dimensional SDS-PAGE (8 or $10.5 \%, \mathrm{w} / \mathrm{v}$, acrylamide) was performed according to Laemmli (1970). When alkaline phosphatase activity had to be revealed, proteins were solubilized in $2 \%(w / v)$ SDS but the addition of thiol reagents and heat treatment were omitted in the solubilization procedure.

Two-dimensional PAGE was done as described by O'Farrell (1975), with the following modifications: a pH gradient was established using ampholines with a $\mathrm{pH}$ range 3.5-10 (LKB) and proteins were solubilized by a twostep procedure. First, samples were treated with $0.5 \% \mathrm{SDS}$ for $30 \mathrm{~min}$ at room temperature. Second, $10 \%(\mathrm{w} / \mathrm{v})$ 
Nonidet P40 (NP40) was added in order to obtain a $2 \%(\mathrm{w} / \mathrm{v})$ final concentration and the mixture was diluted 1 in 5 with a buffer containing $9.5 \mathrm{M}$-urea, $2 \%(\mathrm{w} / \mathrm{v}) \mathrm{NP} 40$ and $2 \%(\mathrm{w} / \mathrm{v})$ ampholines (pH range $3 \cdot 5-10)$. Then proteins $(20-50 \mu \mathrm{g})$ were loaded on isolelectric focusing gels and electrophoresis was carried out as described by O'Farrell (1975). Before being run in the second dimension, gels were first washed twice with a mixture of $20 \%(\mathrm{v} / \mathrm{v})$ ethanol and $1 \%(\mathrm{v} / \mathrm{v})$ acetic acid in order to remove ampholines, and then equilibrated in $0.0625 \mathrm{M}-\mathrm{Tris} / \mathrm{HCl}(\mathrm{pH} \mathrm{6.8)}$ containing $2 \%(\mathrm{w} / \mathrm{v})$ SDS and $10 \%(\mathrm{w} / \mathrm{v})$ glycerol. The $\mathrm{pH}$ range of the gradient in isoelectric focusing gels was measured as indicated by O'Farrell (1975).

Detection of alkaline phosphatase on polyacrylamide gels. After one- or two-dimensional PAGE, gels were washed twice in $0.5 \mathrm{M}$-Tris/ $\mathrm{HCl} \mathrm{pH} \mathrm{8.5,1} \mathrm{mM-ZnCl}, 2 \mathrm{mM}-\mathrm{MgCl}_{2}, 2 \%(\mathrm{v} / \mathrm{v})$ Triton X-100 $(2 \times 20 \mathrm{~min})$ and twice in $0.5 \mathrm{M}-$ Tris/ $\mathrm{HCl} \mathrm{pH} 8 \cdot 5,0 \cdot 1 \mathrm{mM}-\mathrm{ZnCl}_{2}, 1 \mathrm{mM}-\mathrm{MgCl}_{2}, 2 \%(\mathrm{v} / \mathrm{v})$ Triton X-100 for $20 \mathrm{~min}$, with gentle agitation. Alkaline phosphatase activity was revealed as described by Von Tigerstrom \& Stelmaschuck (1985).

\section{RESULTS}

Kinetics of production of E. coli and Z. mobilis alkaline phosphatases

The two organisms were grown under low phosphate concentration and alkaline phosphatase activity was assayed. No activity was detected in the culture medium for either strain after removal of cells. The cell-bound activity was assayed directly on the whole culture after toluene treatment of the cells. The results (Fig. 1) indicated that both strains utilized phosphate at the same rate, lowering its concentration from $2.6-2.8 \times 10^{-4} \mathrm{M}$ to around $0.7 \times 10^{-4} \mathrm{M}$ after 3.5 generations. In contrast, the specific activity curves for alkaline phosphatase were markedly different. With $E$. coli, no activity was detected until the phosphate concentration was $10^{-4} \mathrm{M}$. Then there was a sharp increase, up to 350 units $\mathrm{mg}^{-1}$, in one generation (doubling time was $0.5 \mathrm{~h}$ ). With $Z$. mobilis, the specific activity of alkaline phosphatase was almost constant during the whole growth curve (doubling time was $2 \cdot 3 \mathrm{~h}$ ). After three generations the activity in $Z$. mobilis was 50 units $\mathrm{mg}^{-1}$, a value $8 \cdot 4$-fold lower than that in $E$. coli. These results suggest that the phosphate regulation of the $Z$. mobilis alkaline phosphatase is different from that in $E$. coli. The biosynthesis of the enzyme in $Z$. mobilis is not completely repressed at phosphate concentrations near 2.6-2.8 $\times 10^{-4} \mathrm{M}$ as in $E$. coli. Furthermore, there is no derepression at low phosphate concentration $\left(10^{-4} \mathrm{M}\right)$. This quite unusual regulation may be explained by either a constitutive enzyme in $Z$. mobilis or a different sensitivity to phosphate repression.

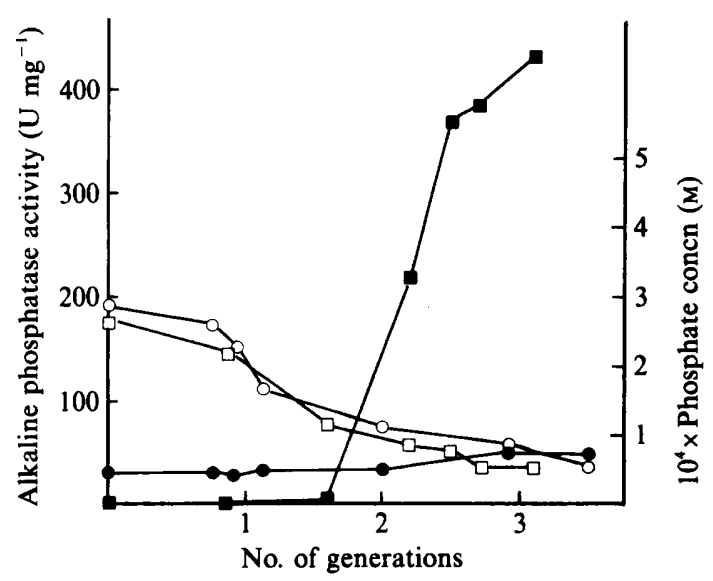

Fig. 1. Alkaline phosphatase activity during growth of $E$. coli $\mathrm{K} 12$ and Z. mobilis ZM4. Cells were grown in the low-phosphate media, and samples were withdrawn at regular time intervals and either toluene-treated for alkaline phosphatase assay, or centrifuged $\left(7000 \mathrm{~g}, 5 \mathrm{~min}, 4^{\circ} \mathrm{C}\right)$. Phosphate remaining in the medium was estimated in the supernatant, and protein assayed in the pellet. Phosphate concentration: $O, Z$. mobilis; $\square, E$. coli. Enzyme activity:,$Z$. mobilis; $\square, E$. coli. 


\section{Table 1. Subcellular localization of alkaline phosphatase}

The crude extract was obtained by disruption of cells with a French press and was submitted to highspeed centrifugation $\left(170000 \mathrm{~g}, 90 \mathrm{~min}, 4^{\circ} \mathrm{C}\right)$. The pellet was resuspended in $10 \mathrm{mM}-\mathrm{Tris} / \mathrm{HCl}(\mathrm{pH} 7.4)$ and enzyme activities were assayed in the pellet and in the supernatant. Results are mean values of two separate experiments, \pm the range. Total activities are expressed in units; specific activities are expressed in units (mg protein) ${ }^{-1}$. The numbers in parentheses show the percentage of the total activity recovered in the pellet and in the supernatant.

\begin{tabular}{|c|c|c|c|}
\hline & Crude extract & Pellet & Supernatant \\
\hline \multicolumn{4}{|l|}{ Alcohol dehydrogenase } \\
\hline Total activity & $113 \cdot 5 \pm 3$ & $\begin{array}{c}7.05 \pm 3 \\
(6 \cdot 0)\end{array}$ & $\begin{array}{c}111 \cdot 5 \pm 22 \\
(94 \cdot 0)\end{array}$ \\
\hline Specific activity & $3 \cdot 1 \pm 0 \cdot 4$ & $0.47 \pm 0.1$ & $5.3 \pm 0.85$ \\
\hline \multicolumn{4}{|l|}{ NADH oxidase } \\
\hline Total activity & $5 \cdot 25 \pm 0.7$ & $4.0 \pm 0.4$ & $0.26 \pm 0.08$ \\
\hline Specific activity & $0.15 \pm 0.03$ & $0.41 \pm 0.1$ & $0.013 \pm 0.005$ \\
\hline \multicolumn{4}{|l|}{ Alkaline phosphatase } \\
\hline Total activity & $4957 \pm 251$ & $\begin{array}{c}4036 \pm 484 \\
(86)\end{array}$ & $\begin{array}{c}649 \cdot 7 \pm 148 \cdot 7 \\
(14)\end{array}$ \\
\hline Specific activity & $139 \pm 8$ & $290 \pm 27$ & $31.9 \pm 8$ \\
\hline
\end{tabular}

\section{Effect of phosphate concentration on alkaline phosphatase biosynthesis}

$Z$. mobilis was grown in the low-phosphate medium supplemented with 1,10 or $100 \mathrm{~mm}$ $\mathrm{KH}_{2} \mathrm{PO}_{4}$. Growth of the bacteria was almost identical in all cases. The specific activity of alkaline phosphatase expressed as a percentage of the control was almost the same for media containing 1,10 or $100 \mathrm{mM}-\mathrm{KH}_{2} \mathrm{PO}_{4}$ (respectively $98 \pm 10,103 \pm 10$ and $110 \pm 2$; means $\pm \mathrm{SD}$ ), and not significantly different from the control without added phosphate. In addition, the specific activity was constant during the growth phase, as observed for the medium without added phosphate (Fig. 1). For this experiment, the activity was assayed on cells which were first centrifuged and then resuspended in $10 \mathrm{mM}$-Tris/ $\mathrm{HCl} \mathrm{pH} 7.4$ before toluene treatment. This treatment was necessary since a strong inhibition of alkaline phosphatase activity by phosphate was observed. In a separate experiment it was found that a phosphate concentration of $2.5 \mathrm{~mm}$ in the assay mixture resulted in $50 \%$ inhibition of the enzyme activity.

From these results it appears clearly that the biosynthesis of alkaline phosphatase of $Z$. mobilis was not repressed by high phosphate concentrations. In all the conditions tested, the enzyme specific activity was constant, which greatly favours the hypothesis of an alkaline phosphatase constitutively expressed in $Z$. mobilis.

\section{Subcellular location of the alkaline phosphatase}

Z. mobilis cells were grown in the low-phosphate medium and disrupted by passage through a French pressure cell. Two subcellular fractions were obtained after ultracentrifugation of the crude extract: a soluble fraction (supernatant) containing mainly cytoplasmic and periplasmic components ( $94 \%$ of the alcohol dehydrogenase activity), and a pellet enriched in membrane components ( $94 \%$ of the NADH oxidase activity) (Table 1). The fact that $86 \%$ of the alkaline phosphatase activity was recovered in the pellet fraction suggests a membrane location for this enzyme. Similar results were obtained with cells disintegrated by ultrasonic treatment (data not shown).

To confirm the subcellular location of alkaline phosphatase, two other methods were tested: spheroplast formation, and osmotic shock. Z. mobilis cells converted to spheroplasts were centrifuged to obtain a supernatant containing periplasmic enzymes and a spheroplast pellet containing the majority of the NADH oxidase activity (Table 2). The alkaline phosphatase activity was mainly $(73 \%)$ found in the pellet fraction. After osmotic shock treatment of (intact) cells, $94 \pm 2 \cdot 2 \%$ of the alkaline phosphatase remained cell-associated. No lysis, as indicated by 
Table 2. Alkaline phosphatase localization after spheroplast formation

\begin{abstract}
Spheroplasts were harvested $\left(10000 \mathrm{~g}, 5 \mathrm{~min}, 4^{\circ} \mathrm{C}\right)$, resuspended in $10 \mathrm{~mm}$-Tris/ $\mathrm{HCl}(\mathrm{pH} 7.4)$ and ultrasonically disrupted. Alcohol dehydrogenase and alkaline phosphatase activities were assayed in the pellet (spheroplast fraction) and in the supernatant (culture medium). Results are expressed as percentages of the total activity recovered in the pellet and in the supernatant. They are mean values of two separate experiments, \pm the range.
\end{abstract}

$\begin{array}{lcc} & \begin{array}{c}\text { Spheroplast fraction } \\ \text { (pellet) }\end{array} & \begin{array}{c}\text { Culture medium } \\ \text { (supernatant) }\end{array} \\ \text { Alcohol dehydrogenase } & 98 \cdot 7 \pm 0.8 & 1 \cdot 3 \pm 0.8 \\ \text { NADH oxidase } & 91 \cdot 8 \pm 2 \cdot 5 & 8 \cdot 2 \pm 2 \cdot 5 \\ \text { Alkaline phosphatase } & 72 \cdot 8 \pm 4 \cdot 7 & 27 \cdot 2 \pm 4 \cdot 7\end{array}$

the alcohol dehydrogenase assay (more than $99 \%$ cell-associated), or solubilization of NADH oxidase (less than $4 \%$ in the supernatant) occurred. This result is in agreement with a nonperiplasmic location of alkaline phosphatase in $Z$. mobilis.

\title{
Effect of Sarkosyl on Z. mobilis membranes
}

The effect of the detergent Sarkosyl on the envelope of $Z$. mobilis was investigated to obtain information on the attachment of alkaline phosphatase to membranes. Sarkosyl preferentially solubilizes inner-membrane proteins in E. coli (Filip et al., 1973) and in Z. mobilis (Michel et al., 1985). However, solubilization of some outer-membrane proteins with Sarkosyl has also been reported (Chopra \& Shales, 1980). The membrane fraction obtained by ultracentrifugation of a crude extract was treated with 0.5 and $1 \%(\mathrm{w} / \mathrm{v})$ Sarkosyl. The alkaline phosphatase was solubilized during this treatment, since respectively $62 \pm 3 \%$ and $73 \pm 2.8 \%$ of the activity was recovered in the supernatant after ultracentrifugation of the treated membranes. No NADH oxidase activity could be detected after Sarkosyl treatment in either the pellet or the supernatant fraction. This experiment further confirms the membrane location of the alkaline phosphatase of Z. mobilis.

\section{Detection of alkaline phosphatase activity on polyacrylamide gels}

The total proteins from $Z$. mobilis cells were separated by one-dimensional SDS-PAGE (Fig. 2). Renaturation of alkaline phosphatase activity and detection on the gel, as described in Methods, revealed one band of molecular mass $56 \mathrm{kDa}$. Two-dimensional PAGE revealed two reactive spots (Fig. 3), indicative of the existence of two isoenzymes (although it cannot be excluded that the occurrence of two forms of the enzyme may have arisen artefactually by deamination of asparagine or glutamine residue(s) in the native enzyme). These two forms exhibited the same molecular mass $(56 \mathrm{kDa})$ but slightly different isoelectric points (approximately 6.6 and 6.7). The two isoenzymes were detected by both activity staining (Fig. $3 a$ ) and protein staining (Fig. 3 b). They belong to a group including the more basic envelope proteins of $Z$. mobilis. This group is mainly formed of outer-membrane proteins (Azoulay, 1986). The separation of all the membrane proteins was not very efficient on the two-dimensional gel because of the lack of treatment with thiol reagent and heating necessary for activity detection.

\section{DISCUSSION}

The biosynthesis of the hydrolytic enzyme alkaline phosphatase is generally repressed by phosphate (Torriani, 1960; Cheng et al., 1970b; Von Tigerstrom, 1984). This is not the case for the ethanogenic bacterium $Z$. mobilis, in which alkaline phosphatase activity is expressed constitutively, as shown by our results. The enzyme is synthesized at a constant level during growth in batch culture, even in the presence of $100 \mathrm{~mm}-\mathrm{KH}_{2} \mathrm{PO}_{4}$. Such a phosphateirrepressible enzyme is rare but not exceptional. Two other bacteria, Capnocytophaga and Bacteroides ruminicola, synthesize constitutive and phosphate-irrepressible alkaline phosphatase (Poirier \& Holt, 1983; Cheng \& Costerton, 1973). Another special feature of the Z. mobilis 


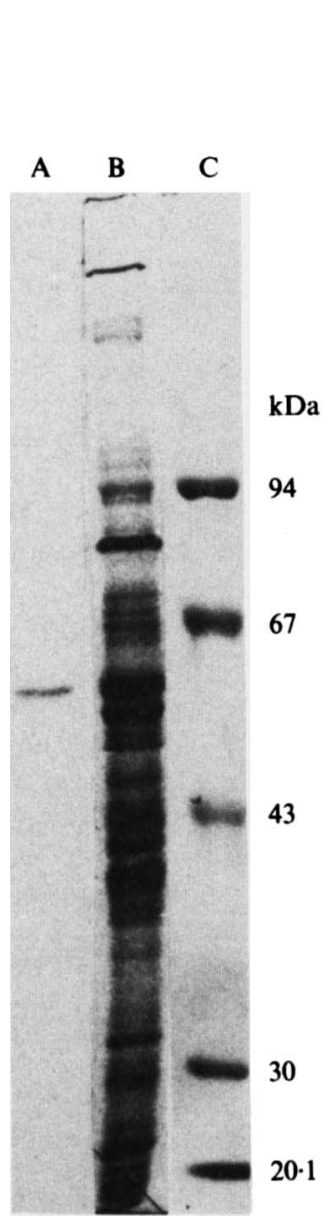

Fig. 2
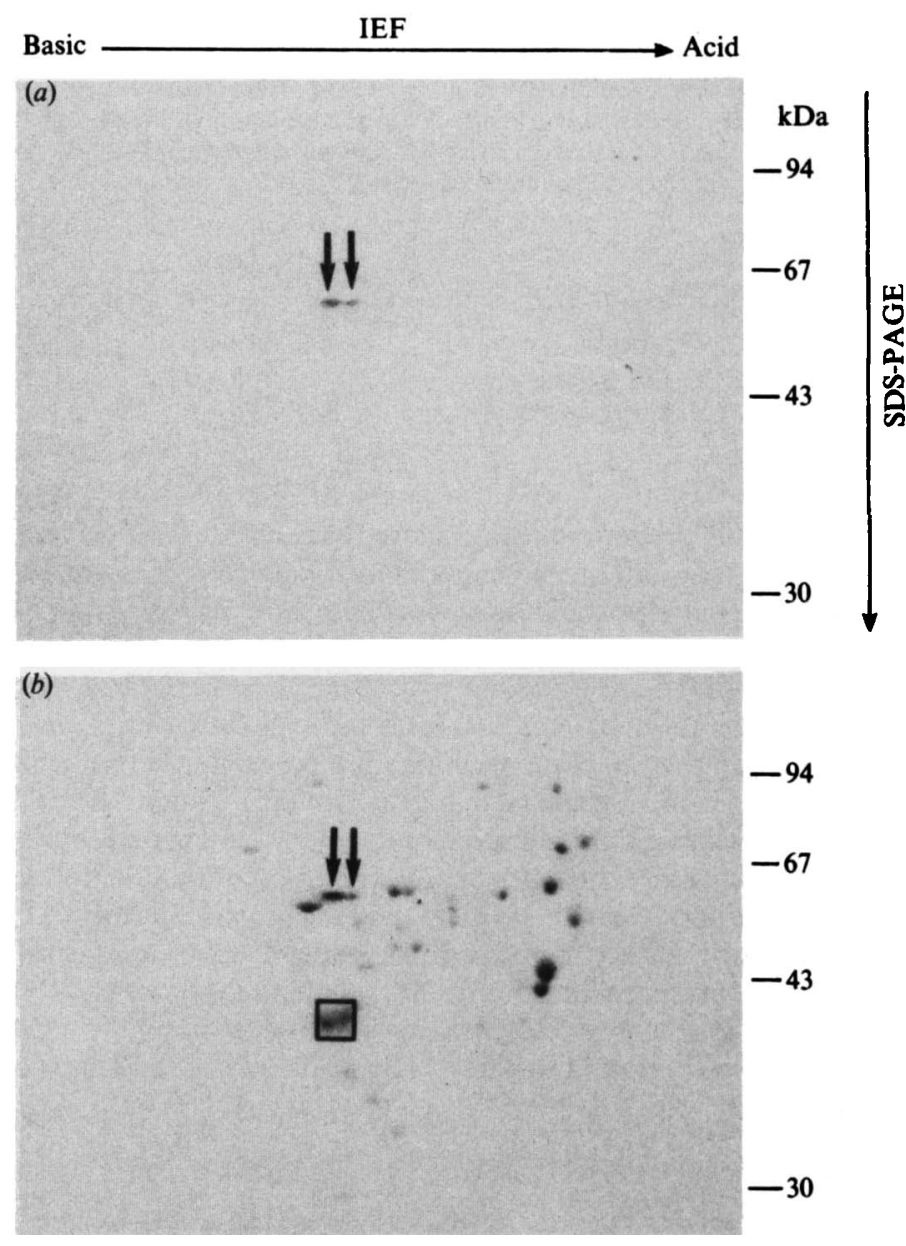

Fig. 3

Fig. 2. Detection of alkaline phosphatase activity on polyacrylamide gel. Proteins $(25 \mu \mathrm{g})$ were separated in an $8 \%(\mathrm{w} / \mathrm{v})$ polyacrylamide gel containing $0.2 \%$ SDS. Lanes: A, activity staining of the alkaline phosphatase; B, Coomassie blue staining; C, molecular mass markers (phosphorylase $b, 94$ $\mathrm{kDa}$; bovine serum albumin, $67 \mathrm{kDa}$; ovalbumin, $43 \mathrm{kDa}$; carbonic anhydrase, $30 \mathrm{kDa}$; soybean trypsin inhibitor, $20 \cdot 1 \mathrm{kDa}$ ).

Fig. 3. Two-dimensional electrophoretic analysis of alkaline phosphatase. Isoelectric focusing (IEF) was performed as described in Methods, and the second dimension (SDS-PAGE) in a $10.5 \%(\mathrm{w} / \mathrm{v})$ polyacrylamide gel containing $0.2 \%$ SDS. (a) Activity staining of the alkaline phosphatase; (b) Coomassie blue staining. Arrows indicate the position of isoenzymes, and the square indicates that of the major outer-membrane protein. Positions of molecular mass standards are indicated on the right (proteins as for Fig. 2). Only the relevant portion of the gel is shown.

alkaline phosphatase is its low specific activity, which is at least 8.4 times lower than that in $E$. coli after derepression. This low activity could be related to the higher doubling time of $Z$. mobilis compared to that of $E$. coli $(2.3 \mathrm{~h}$ and $0.5 \mathrm{~h}$ in our conditions). The constitutive alkaline phosphatase may also have a specific function in phosphate metabolism of the poorly efficient energy-generating system of $\boldsymbol{Z}$. mobilis.

The cellular location of the alkaline phosphatases of Gram-negative bacteria is usually the periplasm (Neu \& Heppel, 1965; Cheng et al., 1970 b; Cheng \& Costerton, 1973; Bhatti et al., 
1976; Poirier \& Holt, 1983). These enzymes are recovered in the supernatant after ultracentrifugation of disrupted cells, in the culture medium during spheroplasting and in the extracellular fluid after osmotic shock (Neu \& Heppel, 1965; Nossal \& Heppel, 1966; Bhatti et al., 1976). Our results show that the Z. mobilis alkaline phosphatase behaves differently, strongly suggesting a membrane location. However, some studies have emphasized possible misleading results obtained by biochemical techniques (Cheng \& Costerton, 1973; Randall et al., 1987). For instance, lysozyme treatment or spheroplasting (methods used for E. coli or Pseudomonas aeruginosa) are not efficient in releasing the alkaline phosphatase of $\boldsymbol{B}$. ruminicola although it has been shown to be periplasmic using improved electron microscopy techniques (Cheng \& Costerton, 1973). These apparently conflicting results may be explained by the occurrence of strong interactions between the enzyme and some structural components of the envelope. Therefore, the exact location of the alkaline phosphatase in $Z$. mobilis cannot be established solely on the basis of biochemical methods. Additional electron microscopy work is necessary.

It should be further pointed out that in $Z$. mobilis, at present, no periplasmic enzyme marker is available. The 5 -nucleotidase cannot be assayed in the presence of a phosphateirrepressible phosphatase since the assay is based on the determination of phosphate enzymically released from AMP (Neu \& Heppel, 1965; Nossal \& Heppel, 1966). Nevertheless, the osmotic shock treatment is most probably efficient in $Z$. mobilis. Indeed, the endoglucanase $Z$ gene of Erwinia chrysanthemi transferred into Z. mobilis is expressed in this bacterium as a cellassociated enzyme which is released in the shock fluid after osmotic shock (Brestic-Goachet, 1988).

Treatment with the detergent Sarkosyl gives further evidence for a membrane location of alkaline phosphatase. It also provides a method of enzyme solubilization which may help enzyme purification. Work is in progress in our laboratory to purify the enzyme to homogeneity and to determine its cellular location using other techniques, which include inner and outer membrane separation and immunoelectron microscopy.

This work was supported by a grant from the Communauté Economique Européenne (contract EN3B/B1/194/F). Professor A. Lazdunski is thanked for helpful suggestions and discussions.

\section{REFERENCES}

AMEs, B. \& DuBIN, J. D. (1960). Role of polyamines in the neutralization of bacteriophage DNA. Journal of Biological Chemistry 235, 769-775.

Azoulay, T. (1986). Effets de la chaleur et de l'éthanol sur Zymomonas mobilis. Thèse, Université, d'AixMarseille II, France.

BARATTI, J. \& Bu'lock, J. D. (1986), Zymomonas mobilis: a bacterium for ethanol production. Biotechnology Advances 4, 95-115.

BECKWITH, J. (1987). Protein secretion and use of alkaline phosphatase. Secretion of phosphaterelated proteins. In Phosphate Metabolism and Cellular Regulation in Microorganisms, pp. 71-72. Edited by A. Torriani-Gorini, F. G. Rothman, S. Silver, A. Wright \& E. Yagil. Washington, DC: American Society for Microbiology.

Bhatti, A. R., De Voe, I. W. \& Ingram, J. M. (1976). The release and characterization of some periplasmlocated enzymes of Pseudomonas aeruginosa. Canadian Journal of Microbiology 22, 1425-1429.

BrEstiC-GOACHET, N. (1988). Amélioration génétique de Zymomonas mobilis: mutagénèse et transfert de gènes d'hydrolases. Thèse, Université d'Aix-Marseille I, Françe.

Bringer, S., Hartner, T., Poralla, K. \& Sahm, H.
(1985). Influence of ethanol on the hopanoid content and the fatty acid pattern in batch and continuous cultures of Zymomonas mobilis. Archives of Microbiology 140, 312-316.

Cheng, K. J. \& Costertón, J. W. (1973). Localization of alkaline phosphatase in three Gram-negative rumen bacteria. Journal of Bacteriology 116, 424-440.

Cheng, K. J., Ingram, J. M. \& Costerton, J. W. $(1970 a)$. Release of alkaline phosphatase from cells of Pseudomonas aeruginosa by manipulation of cation concentration and pH. Journal of Bacteriology 104, 748-753.

Cheng, K. J., Ingram, J. M. \& Costerton, J. W. $(1970 b)$. Alkaline phosphatase localization and spheroplast formation of Pseudomonas aeruginosa. Canadian Journal of Microbiology 16, 1319-1324.

Chopra, I. \& Shales, S. J. S. (1980). Comparison of polypeptide composition of $E$. coli outer membranes prepared by two methods. Journal of Bacteriology 144, 425-427.

Doelle, H. W., Preusser, H. J. \& Rostek, M. (1982). Electron microscopic investigations of $Z$. mobilis cells grown in low and high glucose concentrations. European Journal of Applied Microbiology and Biotechnology 16, 136-141. 
Enequist, H. C., Hirst, T. R., Harayama, S., Hardy, S. J. S. \& RANDALL, L. L. (1981). Energy is required for maturation of exported proteins in Escherichia coli. European Journal of Biochemistry 116, 227-233.

Filip, C., Fletcher, G., WulfF, J. L. \& Earhart, C. F. (1973). Solubilization of the cytoplasmic membrane of Escherichia coli in exponential phase. Journal of Bacteriology 115, 717-722.

Garen, A. \& LeVinthal, C. (1960). A fine structure genetic and chemical study of the enzyme alkaline phosphatase. Biochimica et biophysica acta 38, 470 483.

INGRAM, L. O. \& BuTTKE, T. M. (1984). Effect of alcohols on microorganisms. Advances in Microbial Physiology 25, 254-290.

LAEMMLI, U. K. (1970). Cleavage of structural proteins during the assembly of the head of bacteriophage T4. Nature, London 227, 680-685.

Michel, G. P. F., Azoulay, T. \& Starka, J. (1985). Ethanol effect on the membrane protein pattern of Zymomonas mobilis. Annales de l'Institut Pasteur/ Microbiologie 136A, 173-179.

MONTENECOURT, B. S. (1985). Zymomonas, a unique genus of bacteria. In Biology of Industrial Microorganisms, pp. 261-269. Edited by A. L. Demain \& N. A. Salomon. Menlo Park: Benjamin \& Cummings.

NEU, H. C. \& HEPPEL, L. A. (1965). The release of enzymes from Escherichia coli by osmotic shock and during formation of spheroplasts. Journal of Biological Chemistry 240, 3685-3692.

Nossal, N. G. \& HePpel, L. A. (1966). The release of enzymes by osmotic shock from Escherichia coli in exponential phase. Journal of Biological Chemistry 241, 3055-3062.

O'FARRELL, P. H. (1975). High resolution two dimensional electrophoresis of proteins. Journal of Biological Chemistry 250, 4007-4021.

Osborn, M. J., Gander, J. E., Parisi, E. \& Carson, J. (1972). Mechanism and assembly of the outer membrane of $S$. typhimurium. Isolation and characterization of cytoplasmic and outer membrane. Journal of Biological Chemistry 247, 3962-3972.
Poirier, T. P. \& Holt, S. C. (1983). Acid and alkaline phosphatases of Capnocytophaga species. I. Production and cytological localization of the enzymes. Canadian Journal of Microbiology 29, 1350-1360.

Randall, L. L., HARDY, S. J. S. \& Thom, J. R. (1987). Export of proteins: a biochemical view. Annual Review of Microbiology 41, 507-541.

Schaecterle, G. R. \& Pollach, R. L. (1975). A simplified method for the quantitative assay of protein in biological material. Analytical Biochemistry 51, 654-655.

Swings, J. \& DE LEY, J. (1977). The biology of Zymomonas. Bacteriological Reviews 41, 1-46.

Tornabene, T. G., Holzer, G., Bittner, A. S. \& GroHMAN, K. (1982). Characterization of the total extractable lipids of Z mobilis. Canadian Journal of Microbiology 28, 1107-1118.

TORRIANI, A. (1960). Influence of inorganic phosphate in the formation of phosphatases by Escherichia coli. Biochimica et biophysica acta 38, 460-479.

TORRIANI, A. (1966). Alkaline phosphatase from Escherichia coli. In Procedures in Nucleic Acid Research, pp. 224-235. Edited by G. L. Cantoni \& D. R. Davis. Harper and Row.

VON TIGerstrom, R. G. (1984). Production of two phosphatases by Lysobacter enzymogenes and purification and characterization of the extracellular enzyme. Applied and Environmental Microbiology 47, 693-698.

Von Tigerstrom, R. G. \& Stelmaschuk, S. (1985). Localization of the cell-associated phosphatase in Lysobacter enzymogenes. Journal of General Microbiology 131, 1611-1618.

WelsCH, M. (1958). Formation de protoplastes d'Escherichia coli sous l'influence de la glycine et d'autres acides aminés. Pathologie und Bakteriologie 21, 741-768.

Willis, R. C., Morris, R. G., Cirakoglu, C., SchellenberG, G. D., Gerber, N. H. \& Furlong, C. E. (1974). Preparation of the periplasmic binding proteins of Salmonella typhimurium and Escherichia coli. Archives of Biochemistry and Biophysics 161, 64 75. 